gradient from north-westerly slope towards southeasterly slope and the suction gradient created by increased evaporation on the south-easterly slope favoured the movement of water along with the dissolved salts from the north-westerly slope to the south-easterly slope, thus bringing about a fivefold decrease of salts on the north-westerly slope as compared with that on the southeasterly slope.

Based on these findings, a set of new ridges was made on a contiguous piece of saline soil to investigate the effect of the technique explained above on the stand and growth of cabbage seedlings. On January 10, 1966, cabbage seedlings were transplanted $1 \mathrm{ft}$. apart on north-westerly and south-easterly slopes; the ridge top of the seedbeds was $8 \mathrm{ft}$. long. The experiment was replicated eight times. Weights of green and dry matter of the plants which survived 45 days after transplanting woro recorded in each roplication. The results are presented in Table 2.

Table 2. STAND AND GROWTH OF 45-DAY-OHD CABBAGE SERDLINGS TRANS-

\begin{tabular}{|c|c|c|c|c|}
\hline \multicolumn{5}{|c|}{ PLANTED ON RIDGED PLAN'BEDS } \\
\hline $\begin{array}{l}\text { Planting site on the } \\
\text { ridge }\end{array}$ & $\begin{array}{l}\text { Stands/ } \\
\text { row }\end{array}$ & $\underset{\text { Weight }}{\text { Fresh }}$ & $\begin{array}{l}\text { ants }(g) \\
\text { Dry }\end{array}$ & $\begin{array}{l}\text { Per cent } \\
\text { moisture }\end{array}$ \\
\hline $\begin{array}{l}\text { Yorth-westerly slope } \\
\text { South-easterly slope } \\
\text { Ridge top } \\
\text { E. }\end{array}$ & $\begin{array}{l}8 \cdot 0 \\
4 \cdot 5 \\
1 \cdot 0 \\
0 \cdot 88 \\
2 \cdot 67\end{array}$ & $\begin{array}{c}16 \cdot 5 \\
4 \cdot 3 \\
2 \cdot 8 \\
0 \cdot 46 \\
1 \cdot 36\end{array}$ & $\begin{array}{l}2 \cdot 8 \\
0.9 \\
0.6 \\
0.55 \\
1.67\end{array}$ & $\begin{array}{l}83 \cdot 0 \\
79 \cdot 1 \\
78 \cdot 6 \\
-\end{array}$ \\
\hline
\end{tabular}

A hundred per cent stand of the cabbage transplants became established on the north-westerly (desalinized) slope whereas a mortality of $\mathbf{4 3 . 7 5}$ per cent and 87.5 per cent was observed on the south-easterly slope and the ridge top respectively. Likewise, the growth of transplants on the north-westerly slope was significantly more luxuriant than on the south-easterly slope or the ridge top as indicated by the fresh and dry weight accumulation of each plant. The relatively greater reduction observed in fresh weight than in dry weight of plants on the salinized sites (south-easterly slope and ridge top) is indicative of the fact that the plants suffered as a result of reduced availability of water caused by high salt concentration. This is borne out by the moisture percentage of the plants.

The results reported here show that solar radiation is a potential source of energy which can be harnessed in winter to desalinize the north-wosterly slope of the ridges running from north-east to south-west. This will ensure satisfactory stand and growth of crop plants on saline soils. The technique used here does not involve any additional investment except to adjust the ridge direction of the plantbeds in such a way that solar radiation is intercepted at an angle greater than its incidence on flat land and is focused on one slope of the ridge for longor duration than on the other slope of the ridge.

We are grateful to Dr. O. P. Gautam, head of the Agronomy Division, for providing facilities to conduct the experiments.

S. S. BAINS

K. N. SrNGH

Division of Agronomy,

Indian Agricultural Research Institute,

New Delhi, India.

${ }^{2}$ U.S.D.A. Agriculture Handbook No. 60 (1954).

\section{Surface Area-a Rapid Measure of Wilting Point of Soils}

WILTING point is the lower limit at which water is available to plants. The knowledge of moisture content of the soil at this point is an important consideration if available water resources are to be used properly for irrigation purposes. Several methods of determination of wilting point have been reported. Well known methods are the 15-atm. percentage ${ }^{1}$ and the sunflower method ${ }^{2}$. These methods, however, have not been widely used. The equipment in the former case is very costly, while the second is a rather long method. We therefore tried to find some soil property related to the wilting point which was easy to determine.

Several workers ${ }^{3-5}$ have reported that wilting point is closely related to the percentage of clay in the soil (accurato determination of which requires a lengthy procedure). Surface area, on the other hand, is a property which depends not only on the amount of clay but also on the nature of clay minerals present, a factor known to influence moisture retention by soils. In the present investigation, seventy-nine soil samples were collected from fourteen profiles in semi-arid regions of the Hissar district in Punjab. Surface area was determined by the rapid method proposed by Carter et al.$^{6}$. Calcium saturated soil samples $(1 \cdot \mathrm{lg})$ were treated with $1 \mathrm{ml}$. of ethylene glycol-monoethyl ether. After about $1 \mathrm{~h}$ the samples were subjected to vacuum desiccation over calcium chloride until a constant weight was obtained. This normally took about $2 \mathrm{~h}$. Wilting point was measured by the 15 -atm. percentage method for the same soils, using Richards's pressure membrane apparatus'. The relationship betwcen surface area and wilting point given by tho 15-atm. percentage method is shown graphically in Fig. 1. A high correlation of +0.83 (significant at the 1 per cent level) suggests that surface area could be used as a measure of wilting point. The relationship between the two is given by the regression equation: wilting point (percentage oven dry basis $)=0.094 \times$ surface area $\left(\mathrm{m}^{2} / \mathrm{g}\right)+2 \cdot 4$.

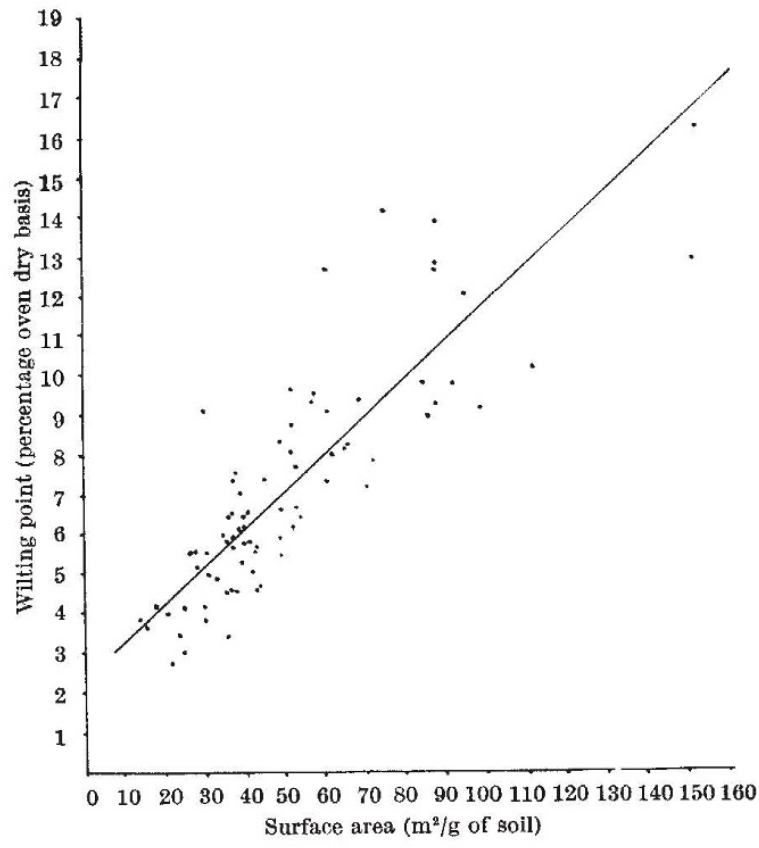

Fig. 1. Relationship between wilting point and surface area of soils.

This method has the advantage of being rapid and less costly, and would be useful oven for soils of varying minoralogical constitution.

I. P. Abrot

B. K. KHOSLA

Department of Soils,

Punjab Agricultural University,

Hissar (Punjab), India.

1 Richards, I. A., and Weaver, L. R., Soil Sci., 56, 331 (1943),

"Veinmeyer, F. J., and Hendrickson, A. H., Soil Sci., 68, 75 (1949).

Lund, Z. F., Soil Sci. Soc, Amer. Proc., 23, 1 (1959).

4 Nielson, D. R., and Shaw, R. H., Soil Sci., 86, 103 (1958).

silcox, J. C., and Spilsbury, R. H., Sci. Agric., 21, 459 (1941).

"Carter, D. L., et al., Soil Sci., 100, 356 (1965).

'Richards, L. A., and Weaver, L. R., Agric. Eng., 28, 451 (1947). 